\title{
Survey of Physical Fitness Levels of Badminton Athletes in Binjai City, Indonesia
}

\author{
Devi Catur Winata ${ }^{\mathrm{a}}$, Bastanta Mujiriah ${ }^{\mathrm{b}}$ \\ ${ }^{a, b}$ Physical Education of Health and Recreation, Sekolah Tinggi Olahraga dan Kesehatan \\ Bina Guna Medan, Indonesia \\ devicatur25@gmail.com ${ }^{\text {a }}$, bastantamujiriah28@gmail.com ${ }^{\text {b }}$
}

\begin{abstract}
Athletes aged 16-19 years is a period towards the peak of achievement that is important to be evaluated from various components including the level of physical fitness. Especially in the sport of badminton, the physical fitness aspect is an important component that must be owned for single and doubles athletes. This research aims to find out the level of physical fitness of badminton athletes in Binjai City, Indonesia. Participants in this study were 10 athletes (ages 16-19 years) at Pusdiklat PB Rada Kota Binjai Indonesia in 2021. The design of this study is descriptive quantitative. The instruments used are physical fitness tests which include a 60-meter running test, elbow hanging test, sitting baring test, upright jump test and 1200-meter running test. Research data collection techniques using test and measurement provisions in physical fitness test guidelines. Data analysis techniques that are through quantitative data obtained are analyzed descriptive statistics, further interpreted in the category of assessment of the physical fitness component of athletes. The results showed that the level of physical fitness with a range of results of 14-17 showed a good category of 7 people $(85 \%)$ and with a range of results of $10-13$ showed a category of less than 3 people $(25 \%)$. So based on the results of research it can be concluded that the level of physical fitness of Badminton Pusdiklat PB Rada Kota Binjai in 2021 is categorized as Good. This research has implications for badminton coaches determining physical exercise programs, techniques, and tactics so that they can be optimal in improving the achievement of their athletes. The contribution of this research is to provide an overview of future research to be able to provide a variety of exercise programs to the optimization of physical fitness of athletes.
\end{abstract}

Keywords: Physical Fitness, Athlete, Badminton, Survey

\begin{abstract}
Abstrak
Atlet Usia 16-19 tahun merupakan masa menuju puncak prestasi yang penting dievaluasi dari berbagai komponen termasuk di antaranya tingkat kebugaran jasmaninya. Khususnya pada olahraga badminton, aspek kebugaran jasmani merupakan komponen penting yang harus dimiliki bagi atlet nomor tunggal maupun ganda. Penelitian ini bertujuan untuk mengetahui tingkat kebugaran jasmani atlet bulutangkis di Kota Binjai, Indonesia. Partisipan dalam penelitian ini adalah 10 atlet (usia 16-19 tahun) di Pusdiklat PB Rada Kota Binjai Indonesia Tahun 2021. Desain penelitian ini yaitu deskriptif kuantitatif. Instrumen yang digunakan adalah tes kebugaran jasmani yang meliputi meliputi tes lari 60 meter,
\end{abstract}


tes gantung siku, tes baring duduk, tes loncat tegak dan tes lari 1200 meter. Teknik pengumpulan data penelitian menggunakan ketentuan tes dan pengukuran dalam panduan tes kebugaran jasmani. Teknik analisis data yaitu dengan yaitu melalui data kuantitatif yang didapat dianalisis statistik deskriptif, selanjutnya diinterpretasikan dalam kategori penilaian komponen kebugaran jasmani atlet. Hasil penelitian menunjukkan bahwa tingkat kebugaran jasmani dengan rentang hasil 14-17 menunjukkan kategori baik sebanyak 7 orang (85\%) dan dengan rentang hasil 10-13 menunjukkan kategori kurang sebanyak 3 orang (25\%). Sehingga berdasarkan hasil penelitian dapat disimpulkan bahwa tingkat kebugaran jasmani alet Bulutangkis Pusdiklat PB Rada Kota Binjai Tahun 2021 dikategorikan Baik. Penelitian ini berimplikasi pada pelatih bulutangkais penentuan program latihan fisik, teknik, dan taktik sehingga dapat optimal dalam meningkatkan prestasi atletnya. Kontribusi penelitian ini adalah memberikan gambaran pada penelitian selanjutnya untuk dapat memberikan variasi program latihan terhadap optimalisasi kebugaran jasmani atlet.

Kata Kunci: Kebugaran Jasmani, Atlet, Olahraga Bulutangkis, Survei

\section{Introduction}

Physical freshness is a physical condition that has something to do with its ability and ability to function in work optimally and efficiently. Realized or not actually physical freshness is one of the needs of human life because the physical freshness is in conjunction with human life (Putra, Purwanto, \& Burhaein, 2021; Widiyono \& Mudiono, 2021; Widodo \& Najibuzzamzam, 2021). Physical freshness is a condition that a person has or achieves in relation to the ability to perform physical activity (Burhaein, Demirci, Lourenço, Németh, \& Phytanza, 2021; Irawan \& Limanto, 2021; Sutopo \& Misno, 2021). Physical freshness is related to health when physical activity can be done without excessive fatigue, maintained for life and as a consequence has a lower risk for chronic disease earlier.

The benefits of physical fitness for the body, among others, can prevent various diseases such as heart, blood vessels, and lungs so as to improve the overall quality of life (Azizah \& Sudarto, 2021; Bompa \& Buzzichelli, 2019; Burhaein, Phytanza, \& Demirci, 2020). With a fit body, life becomes spirited and fun. Physical freshness not only describes health, but is more a way of measuring individuals doing activities every day (Burhaein, Demirci, et al., 2021; Jornan, Intan, \& Hedison, 2013; Piercy et al., 2018). To be able to know and assess the level of physical freshness a person can do by carrying out measurements.

Sports activities to improve achievement are not activities that are as easy as turning the palm of the hand, but require various efforts to increase various factors, such as obstacles and challenges in achieving achievements (Burhaein, 2017; Phytanza, Burhaein, \& Pavlovic, 2021; Putra et al., 2021). Reality shows that with the advancement of science and technology today has accelerated changes in people's lives, including in the effort to improve sports achievement and by itself there is competition in the improvement of achievement (Burhaein, Phytanza, et al., 2020; Ramadhan, Ma'mun, \& Mahendra, 2020). In an effort to improve the achievement of sports, especially the sport of football, then every individual has chosen sports as a field of profession (Ma'mun, Nuryadi, Slamet, \& Abdullah, 2018; Pramantik \& Burhaein, 2019; Purnomo, Tomoliyus, \& Burhaein, 2019). Must try their hardest to solve the problems that are 
obstacles to the realization of the development and improvement of sports achievement. Kususnya in the field of badminton.

Badminton is an individual game that can be done in the way of one person against one person or two people against two people (PBSI, 2016; Ulfian, 2019). What is interesting in this game is the agile reflex movement when the badminton player returns the opponent's ball. Badminton is one of the few types of sports, which can be played by mixed men's and women's squads in regional and national matches (Cinthuja et al., 2015; Singh, 2011). Regarding the purpose and how to play it resembles tennis, both use a rectangular court and a racket to hit an object that is played.

Badminton as one of the popular and popular sports of the game by the people of Indonesia, ranging from children to the level of parents, men and women (Deli, 2017; PBSI, 2016). Badminton is one of the sports that quickly spread and is favored by the community to the corners of the region. The result through this badminton sport, the State of Indonesia can be known in the international world, namely by the achievements achieved by Indonesian athletes (Akbari, Dlis, \& Widiastuti, 2017; PBSI, 2016). By the community of badminton, efforts to achieve badminton must be continuously encouraged and improved to maintain and improve the achievements that have been obtained, in order to bring the fragrant name of the Indonesian State at the world level (Cinthuja et al., 2015; Luo, 2019; Phomsoupha \& Laffaye, 2015).

One aspect of the physical component that must be owned by badminton players is physical fitness. The physical component is the main capital of a person both athletes and nonathletes in carrying out their daily activities (Lloyd \& Oliver, 2012; Pasaribu \& Yudhaprawira, 2020). A person is required to have physical fitness through the enhancement of the physical components that make it up. As for the components that make up of physical fitness there are several sub-aspects. Components of physical fitness include aspects of strength, endurance, flexibility, speed, balance, agility, accuracy, explosiveness and stamina (Bompa \& Buzzichelli, 2019; Burhaein, Ibrahim, \& Pavlovic, 2020; Susilowati \& Suwarjo, 2020). Regular physical fitness exercises will bring benefits as. The first benefit is to build muscle strength and endurance, such as bone and joint strength in addition to supporting appearance in both sports and non-sports activities. The next benefits are increasing aerobic endurance, increasing flexibility, developing calories that allow the body to avoid obesity, reduce stress, and increase happiness (Bompa \& Buzzichelli, 2019; Doyle, Browne, \& Horan, 2020).

Badminton athletes at PUSDIKLAT PB. RADA KOTA BINJAI is the place of formation of badminton athletes training in the city of medan that scores many athletes who excel so that it requires a healthy body condition and healthy stamina in order to get a glorious achievement, therefore it takes a test component that can measure how capable in doing badminton matches with good physical condition can survive in each game so that it can score even better achievements in the future. The importance of physical fitness in badminton athletes PUSDIKLAT PB KOTA BINJAI among others can improve the ability of organs, social emotional, sportsmanship, and spirit of competition. Some studies also mention that physical fitness has a positive correlation with academic achievement. The correlation from previous research seen from the educational point of view of efforts to improve physical fitness has goals including movement formation, achievement formation, social formation, and body growth (Akbari et al., 2017; PBSI, 2016). 
Physical fitness measurements are done with physical freshness tests. To carry out the test, a tool /instrument is required. The Indonesian Physical Freshness Test (TKJI) is one form of instrument to measure the level of physical freshness. In this case it is important to know the level of physical fitness of badminton athletes PUSDIKLAT PB. RADA KOTA BINJAI where in previous exposure researchers revealed that physical fitness is the most important factor for athletes in carrying out daily activities, especially when heading to the games. Based on previous research it is known that there is a positive link between physical fitness and the results of badminton athletes' achievements.

There needs to be scientific proof of the relationship between the physical fitness of students and the achievements of PUSDIKLAT PB badminton athletes. RADA KOTA BINJAI IN 2021 which is one of the training centers for athletes who want to achieve. Researchers tried to prove the linkage through research conducted at PUSDIKLAT PB. RADA KOTA BINJAI. So a research plan was prepared with the title "Physical Fitness Level Survey in PUSDIKLAT PB badminton athletes. RADA KOTA BINJAI IN 2021".

\section{Research Metodology}

\subsection{Participant}

The determination of study participants noticed some of the first elements are populations. Population is the whole subject of the study. The population in this study is all badminton athletes in PUSDIKLAT PB. RADA KOTA BINJAI which numbered 30 people. The next criterion is the determination of the sample to be used as a study participant. The sample is part of the entirety of the research object that is considered to represent the entire population. This sampling is done by purposive random sampling. (Burhaein, Tarigan, Budiana, Hendrayana, \& Phytanza, 2021; Fraenkel, Wallen, \& Hyun, 2012). The criteria used to eliminate the population include active athletes and pass the COVID-19 pandemic health protocol standards in Indonesia. So that the final results were participants in this study as many as 10 athletes with details of 8 men and 2 women.

\subsection{Research Design}

Research design is exposure or draft steps to be done on research (Fraenkel et al., 2012). This research is quantitative research. This type of research is a survey (Fraenkel et al., 2012). The design of this study can be seen in Table 1 .

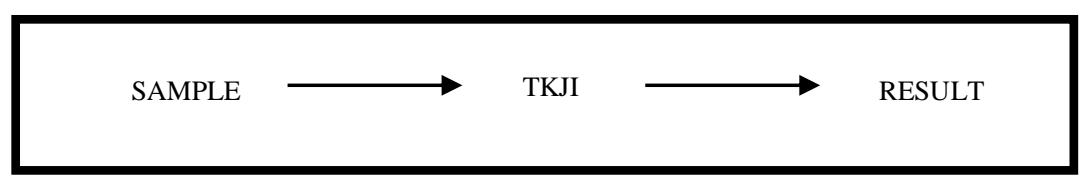

Picture 1. Research Design

\subsection{Instrument}

Intsrumen this study is a physical fitness test in athletes aged 16-19 years. This test has been validated and tested for reliability. Test of passing ability of the ball adopted from the test developed by (Puskesjasrek Depdikbud, 2010). The series of tests taken in the form of: (a) Run 60 meters, (b) Hang elbows 60 seconds, (c) Baring sits 60 seconds, (d) Jump upright, (e) Run 1200 meters. 


\subsection{Data Collection Techniques}

Research data collection is a one-time data collection. In this study, researchers only conducted physical fitness tests without taking preliminary data (pre test). The results of the tests conducted are real conditions in the field how the level of physical fitness of athletes without any treatment increases. Participants took the test alternately with the test sequence, namely running 60 meters, hanging elbows 60 seconds, sitting 60 seconds, jumping upright, running 1200 meters. The location of this data collection is in indoor and outdoor areas (specifically running 60 meters and 1200 meters).

\subsection{Data Analysis}

Analysis of this research data using a quantitative descriptive approach (Fraenkel et al., 2012; Phytanza et al., 2021). The data analysis in this study was assisted using a statistical application, the IBM 24 SPSS. The results of the study obtained were then categorized based on fitness test norms.

Table 1. Norm of the Physical Fitness Test Male Athletes Age 16-19 Years

\begin{tabular}{|c|c|c|c|c|c|c|}
\hline & $\begin{array}{c}\text { Sprint } 60 \\
\text { meters }\end{array}$ & Pull up & $\begin{array}{r}\text { Sit-up } 60 \\
\text { Seconds }\end{array}$ & $\begin{array}{c}\text { Vertical } \\
\text { Jump }\end{array}$ & $\begin{array}{c}\text { Running } 1200 \\
\text { meter }\end{array}$ & Score \\
\hline \multirow{5}{*}{$\stackrel{\mathscr{2}}{\mathcal{Z}}$} & $<8,4 "$ & $>19^{\prime \prime}$ & $>41$ & $>73$ & $<3^{\prime} 14^{\prime \prime}$ & 5 \\
\hline & $8,5^{\prime \prime}-9,8 ”$ & $14 "-18 "$ & $30-40$ & $60-72$ & 3'15' - 4'25" & 4 \\
\hline & $9,9{ }^{\prime \prime}-11,4 ”$ & $9 ",-13 "$ & $21-29$ & $50-59$ & $4 ' 26^{\prime \prime}-5 ' 12 ”$ & 3 \\
\hline & $11,5 "-13,4 "$ & $5 "-8 “$ & $10-20$ & $39-49$ & $5 ' 13^{\prime \prime}-63^{\prime} 3$ & 2 \\
\hline & $>13,5 "$ & $0 "-4 "$ & $0-9$ & $<38$ & > 6’34” & 1 \\
\hline
\end{tabular}

Source: Puskesjasrek Depdikbud (2010)

Table 2. Norm of the Physical Fitness Test Female Athletes Age 16-19 Years

\begin{tabular}{|c|c|c|c|c|c|c|}
\hline & $\begin{array}{c}\text { Sprint } 60 \\
\text { meters }\end{array}$ & Pull up & $\begin{array}{r}\text { Sit-up } 60 \\
\text { Seconds }\end{array}$ & $\begin{array}{c}\text { Vertical } \\
\text { Jump }\end{array}$ & $\begin{array}{c}\text { Running } 1200 \\
\text { meter }\end{array}$ & Score \\
\hline \multirow{5}{*}{$\stackrel{\mathscr{2}}{\mathcal{R}}$} & $<7,2{ }^{\prime}$ & $>19 "$ & $>41$ & $>73$ & $<3{ }^{\prime} 14^{\prime \prime}$ & 5 \\
\hline & $7,3^{\prime \prime}-8,3^{\prime \prime}$ & $14 "-18 "$ & $30-40$ & $60-72$ & 3'15' - 4'25' & 4 \\
\hline & $8.4 "-9,6 "$ & $9 " '-13 "$ & $21-29$ & $50-69$ & 4'26"'- 5'13"' & 3 \\
\hline & $9,7 "-11,0 "$ & $5 "-8 “$ & $10-20$ & $39-49$ & 5'59"'-7’23"' & 2 \\
\hline & > 11.5” & $0 "$ - 4" & $0-9$ & $<38$ & > 6’34' & 1 \\
\hline
\end{tabular}

Source: Puskesjasrek Depdikbud (2010)

Of the five test items, the sum of each item will be converted to see the athlete's physical fitness level.

Table 3. Physical Fitness Classification Norms Aged 16-19 Years

\begin{tabular}{ccc}
\hline No & Jumlah Nilai & Klasifikasi \\
\hline 1 & $22-25$ & Very Good (BS) \\
2 & $18-21$ & Good (B) \\
3 & $14-17$ & Medium (S) \\
4 & $10-13$ & Bad (K) \\
5 & $5-9$ & Very Bad (KS) \\
\hline \multicolumn{3}{c}{}
\end{tabular}




\section{Results and Discussion}

\subsection{Results}

Research that has been conducted in July 2021 has obtained data following the description of the study, for the 60 meter running test item obtained a minimum result of 8.9 seconds and a maximum result of 6.3 seconds with an average result of 7.62 seconds. On the elbow hanging test item obtained a minimum result of 7 and a maximum result of 16 with an average of 13. On the sat baring test item obtained a minimum result of 20 and a maximum result of 30 with an average result of 25 . On the upright jump test item obtained a minimum result of 50 and a maximum result of 70 with an average result of 60 . On the 1200-meter test item obtained a minimum result of 7.00 minutes and a maximum result of 4.00 minutes with an average result of 5.04 minutes. For more details, you can see in the following Table 4.

Table 4. Physical Fitness Test Results

Badminton Athlete Pusdiklat PB. Rada Kota Binjai 2021

\begin{tabular}{clccc}
\hline No & \multicolumn{1}{c}{ Item of Test } & Minimum & Maximum & Average \\
\hline 1 & Sprint 60 Meter & 8,9 seconds & 6,3 seconds & 7,62 \\
\hline 2 & Pull up & 9 & 16 & 13 \\
\hline 3 & Sit up & 20 & 30 & 25 \\
\hline 4 & Vertical jump & $50 \mathrm{~cm}$ & $70 \mathrm{~cm}$ & $60 \mathrm{~cm}$ \\
\hline 5 & Running test 1200 Meter & 7,00 minutes & 4,00 minutes & 5,04 minutes \\
\hline
\end{tabular}

Based on the results of physical fitness tests conducted on badminton athletes Pusdiklat PB. Rada Binjai then obtained the following research data: From 10 badminton athletes Pusdiklat PB. Rada Binjai then obtained 7 students (85\%) obtained a range of grades 18-21 with the category of physical fitness level "Good", while 3 students $(25 \%)$ obtained a range of grades 10-13 with the category of physical fitness level "Less". For more details, you can see in the Table 5 .

Table 5. Physical Fitness Level Category

Athlète de badminton Pusdiklat PB. Rada Binjai en 2021

\begin{tabular}{ccllcc}
\hline No & Range of Value & \multicolumn{2}{c}{ Clasification } & Frequency & Percentage \\
\hline 1 & $22-25$ & Baik Sekali & (BS) & 0 & 0.00 \\
\hline 2 & $18-21$ & Baik & $(\mathrm{B})$ & 7 & 70 \\
\hline 3 & $14-17$ & Sedang & $(\mathrm{S})$ & 3 & 30 \\
\hline 4 & $10-13$ & Kurang & $(\mathrm{K})$ & 0 & 0.00 \\
\hline 5 & $5-9$ & Kurang Sekali & $(\mathrm{KS})$ & 0 & 0.00 \\
\hline \multicolumn{7}{r}{} & Jumlah & & 10 & 100 \\
\hline
\end{tabular}

\subsection{Discussion}

In measuring the level of physical fitness a person can be done by means of physical fitness tests tailored to his age and needs. In this study, the physical fitness test items conducted were a 60-meter running test, body hanging test, sitting baring test, upright jump test and 1200-meter running test. The taking of results and test scores will be guided by the Physical Fitness Test (TKJI) for ages 16-19 years. 
Success in achieving physical fitness is largely determined by the quality of exercise which includes: exercise goals, selection of exercise models, use of exercise facilities and more importantly the dose or dose of exercise described in the concept of FIT (Frecuency, Intensity, and Time) which will be described as follows 1) Frequency is the number of units of exercise per week. To improve fitness it is necessary to exercise 3-5 times in 1 week; 2) Intensity is a quality that indicates the light weight of the exercise. The magnitude of the intensity of the exercise depends on the type and purpose of the exercise; 3) Time is the time or duration required each time exercise to improve lung or heart fitness and weight loss takes 20-60 minutes of exercise timeSuccess in achieving physical fitness is largely determined by the quality of exercise which includes: exercise goals, selection of exercise models, use of exercise facilities and more importantly the dose or dose of exercise described in the concept of FIT (Frecuency, Intensity, and Time) which will be described as follows 1) Frequency is the number of units of exercise per week. To improve fitness it is necessary to exercise 3-5 times in 1 week; 2) Intensity is a quality that indicates the light weight of the exercise. The magnitude of the intensity of the exercise depends on the type and purpose of the exercise; 3) Time is the time or duration required each time exercise to improve lung or heart fitness and weight loss takes 20-60 minutes of exercise time(ACSM, 2020; Pasaribu \& Yudhaprawira, 2020).

The components of physical freshness consist of many sub-aspects. All of these sub-aspects that make up an athlete's physical fitness. These components are a) Heart/circulatory and pulmonary endurance, b) Biochemical adaptability, c) Body shape, d) Muscle strength, e) Muscle explosiveness, f) Muscle endurance, g) Speed, h) Agility, i) Flexibility, j) Reaction speed, k) Coordination (Sonchan, Moungmee, \& Sootmongkol, 2017). These various components are important for badminton athletes to support the optimization of the achievements of athletes.

From the results of the study it is known that there is a level of physical freshness that varies between badminton athletes. This difference can be caused by several factors including food/nutrition, rest, and sports/ exercises regular.(Blair, Lamonte, \& Nichaman, 2018; Bompa \& Buzzichelli, 2019; Burhaein, Tarigan, et al., 2021).

\section{Food/Nutrition Rest}

In order to maintain a decent life every human being needs enough food, both quantity and quality that qualifies a healthy diet balanced, enough energy, and nutrients include: carbohydrates, fats, proteins, vitamins, minerals, and water(Bompa \& Buzzichelli, 2019; Burhaein, Tarigan, et al., 2021). A person consumes less important substances needed by the body will affect the energy produced by the body to carry out daily activities. By consuming a healthy and nutritious diet it will produce energy that is very beneficial for the growth and development of the body, especially for elementary school students. 


\section{Rest}

Rest is very necessary for the optimization of a badminton athlete's training program. Istirahan will give the body the opportunity to do recovery (recovery). Adequate rest has an impact on performance or daily activities are more comfortable and fresh. In a day overnight, generally an athlete aged 16 years and above requires a break of up to 8 hours (Blair et al., 2018; Bompa \& Buzzichelli, 2019).

\section{Sports/Exercises Regular}

Exercising is one of the most effective and comfortable alternatives to gaining fitness because exercising has multi benefits, including physical benefits (increasing the freshness component) psychic benefits (more resistant to stress, better able to concentrate), and social benefits (adding confidence and sara interacting) (Blair et al., 2018; Bompa \& Buzzichelli, 2019).

\section{Conclusion}

Based on the results of the study it can be concluded that the level of physical fitness of Badminton Pusdiklat PB Rada Kota Binjai in 2021 is categorized as Good. This research has implications for badminton coaches determining physical exercise programs, techniques, and tactics so that they can be optimal in improving the achievement of their athletes. The limitation of this study is on the instruments used not yet using physical fitness tests or physical components that are specific to badminton cabor, because it uses common standards of various sports. The contribution of this research is to provide an overview of future research to be able to provide a variety of exercise programs to the optimization of physical fitness of athletes.

\section{References}

ACSM. (2020). The New American College of Sports Medicine FITT Recommendations for Hypertension. Retrieved June 5, 2020, from https://www.acsm.org/docs/defaultsource/files-for-resource-library/fitt-recommendations-forhypertension_update.pdf?sfvrsn=34b7fe2a_2

Akbari, M., Dlis, F., \& Widiastuti. (2017). The effect at muscle power arm, hand-eye coordination, flexibility, and self confidence upon badminton smash skill. Journal of Indonesian Physical Education and Sport, 3(2), 84-95.

Azizah, A. R., \& Sudarto, E. P. (2021). Minat Mengikuti Ekstrakurikuler Bola Voli Siswa Smp Negeri 3 Satu Atap Karangsambung Kecamatan Karangsambung Tahun Ajaran 2019/2020. JUMORA: Jurnal Moderasi Olahraga, 1(01), 35-44. https://doi.org/10.53863/mor.v1i01.132

Blair, S. N., Lamonte, M. J., \& Nichaman, M. Z. (2018). The evolution of physical activity recommendations : how much is. American Journal Clinical Nutrition, 79(5), 913-920. https://doi.org/10.1093/ajen/79.5.913S

Bompa, T. O., \& Buzzichelli, C. (2019). Periodization Theory and Methodology of Training (Sixth). United States.

Burhaein, E. (2017). Aktivitas Permainan Tradisional Berbasis Neurosainslearning Sebagai Pendidikan Karakter Bagi Anak Tunalaras. Jurnal SPORTIF: Jurnal Penelitian Pembelajaran, 3(1), 55. https://doi.org/10.29407/js_unpgri.v3i1.580 
Burhaein, E., Demirci, N., Lourenço, C. C. V., Németh, Z., \& Phytanza, D. T. P. (2021). Coping with the COVID-19 pandemic: the role of physical activity. An international position statement. International Sports Studies, 43(1), 52-70. https://doi.org/10.30819/iss.43-1.05

Burhaein, E., Ibrahim, B. K., \& Pavlovic, R. (2020). The Relationship of Limb Muscle Power, Balance, and Coordination with Instep Shooting Ability : A Correlation Study in Under-18 Football Athletes. International Journal of Human Movement and Sports Sciences, 8(5), 265-270. https://doi.org/10.13189/saj.2020.080515

Burhaein, E., Phytanza, D. T. P., \& Demirci, N. (2020). The development and validation of a revised Friendship Activity Scale and Adjective Checklist for use in the Indonesian Unified Sports program. International Sports Studies, 42(e), 18-28. https://doi.org/10.30819/iss.42-e.03

Burhaein, E., Tarigan, B., Budiana, D., Hendrayana, Y., \& Phytanza, D. T. P. (2021). Physical Activity Level of Students with Disabilities during COVID-19 Pandemic. Jurnal Pendidikan Jasmani Dan Olahraga, 6(2), 19-21. https://doi.org/10.17509/jpjo.v6i2.38547

Cinthuja, P., Jayakody, J. A. O. A., Perera, M. P. M., Weerarathna, W. V. D. N., Nirosha, S. E., Indeewari, D. K. D. C., ... Adikari, S. B. (2015). Physical fitness factors of school badminton players in Kandy district Department of physiotherapy , Faculty of Allied Health Sciences, General Sir John Kotelawala. European Journal of Sports \& Exercise Science, 4(2), 14-25.

Deli, I. T. N. M. (2017). Buku pintar bulutangkis. Jakarta (ID): Anugrah.

Doyle, B., Browne, D., \& Horan, D. (2020). The relationship of aerobic endurance and linear speed on repeat sprint ability performance in female international footballers. International Journal of Human Movement and Sports Sciences, 8(4), 147-153. https://doi.org/10.13189/saj.2020.080407

Fraenkel, J. R., Wallen, N. E., \& Hyun, H. H. (2012). How to design and evaluate research in education. New York: Mc Graw Hill.

Irawan, Y. F., \& Limanto, D. (2021). Pengaruh Kecerdasan Emosi dan Kesiapan Diri Terhadap Pertandingan Pada Pemain Walet Muda Futsal Academy Kebumen Tahun 2020. JUMORA: Jurnal Moderasi Olahraga, I(01), 18-26. https://doi.org/10.53863/mor.v1i01.130

Jornan, J., Intan, W., \& Hedison, P. (2013). Pengaruh latihan fisik aerobic terhadap vo2maks pada mahasiswa pria dengan berat badan lebih (overweight). Jurnal E-Biomedik, 1(2), 15.

Lloyd, R. S., \& Oliver, J. L. (2012). The Youth Physical Development Model: A New Approach to Long-Term Athletic Development. Strength \& Conditioning Journal, 34(3), 61-72.

Luo, Y. J. (2019). The influence of problem-based learning on learning effectiveness in students' of varying learning abilities within physical education. Innovations in Education and Teaching International, 56(1), 3-13. https://doi.org/10.1080/14703297.2017.1389288

Ma'mun, A., Nuryadi, N., Slamet, S., \& Abdullah, C. U. (2018). Indonesia Advanced Sport Development. Indonesia Focus 10th Annual Conference. ASIRPA.

Pasaribu, A. M. N., \& Yudhaprawira, A. (2020). Pelatihan Strength And Conditioning Atlet Bulu Tangkis Di Metland Jakarta Timur. Jurnal ABDIMAS, 3(2), 163-170.

PBSI. (2016). Kriteria dan Parameter Fisik Atlet Masuk Pelatnas dan Atlet Pelatnas. Jakarta: Persatuan Bulutangkis Seluruh Indonesia (PBSI). 
Phomsoupha, M., \& Laffaye, G. (2015). The Science of Badminton: Game Characteristics , Anthropometry, Physiology, Visual Fitness and Biomechanics. Sports Medicine, 45(1), 473-495. https://doi.org/10.1007/s40279-014-0287-2

Phytanza, D. T. P., Burhaein, E., \& Pavlovic, R. (2021). Gross Motor Skills Levels in Children with Autism Spectrum Disorder during the COVID-19 Pandemic. International Journal of Human Movement and Sports Sciences, 9(4), 738-745. https://doi.org/10.13189/saj.2021.090418

Piercy, K. L., Troiano, R. P., Ballard, R. M., Carlson, S. A., Fulton, J. E., Galuska, D. A., ... Olson, R. D. (2018). The physical activity guidelines for Americans. JAMA - Journal of the American Medical Association, 320(19), 2020-2028. https://doi.org/10.1001/jama.2018.14854

Pramantik, I. A. D., \& Burhaein, E. (2019). A Floor Time Approach to Improve Learning Outcomes of the Body Roll to the Side in Adaptive Physical Education Learning: Classroom Action Research Study on Two Cerebral Palsy Students. International Journal of Disabilities Sports and Health Sciences, 2(2), 45-53. https://doi.org/10.33438/ijdshs.652061

Purnomo, I. D., Tomoliyus, T., \& Burhaein, E. (2019). Development of Learning Activities Playing a Ball on a Goal To Improve Manipulative Skills For Lower Class Students. Proceedings of the 1st International Conference on Science and Technology for an Internet of Things. https://doi.org/10.4108/eai.19-10-2018.2281716

Puskesjasrek Depdikbud. (2010). Tes Kesegaran Jasmani Indonesia (TKJI). Jakarta: Departemen Pendidikan dan Kebudayaan Indonesia.

Putra, Y. M., Purwanto, S., \& Burhaein, E. (2021). Effect of Limb Muscle Power Training with Leaps on Athlete's Speed during the COVID-19 Pandemic. International Journal of Human Movement and Sports Sciences, 9(3), 461-465. https://doi.org/10.13189/saj.2021.090310

Ramadhan, M. G., Ma'mun, A., \& Mahendra, A. (2020). Implementasi Kebijakan Olahraga Pendidikan sebagai Upaya Pembangunan Melalui Olahraga Berdasarkan Undang-Undang Sistem Keolahragaan Nasional. JTIKOR (Jurnal Terapan Ilmu Keolahragaan), 5(1), 6980. https://doi.org/10.17509/jtikor.v5i1.23824

Singh, J. (2011). Physical Characteristics and Level of Performance in Badminton: A Relationship Study. Journal of Education and Practice, 2(5), 6-10.

Sonchan, W., Moungmee, P., \& Sootmongkol, A. (2017). The Effects of a Circuit Training Program on Muscle Strenght, Agility, Anaerobic Performance and Cardiovascular Endurance. International Journal of Sport and Health Science, 11(4), 176-179. Retrieved from http://www.statista.com/statistics/275056/total-number-of-health-

Susilowati, A., \& Suwarjo. (2020). Physical-Motor Development in Children at Elementary School - Article Review. Physical Education and Sport Through the Centuries, 7(2), 247255. https://doi.org/10.2478/spes-2020-0020

Sutopo, W. G., \& Misno. (2021). Analisis Kecepatan Tendangan Sabit Pada Pesilat Remaja Perguruan Pencak Silat Tri Guna Sakti Di Kabupaten Kebumen Tahun 2020. JUMORA: Jurnal Moderasi Olahraga, 1(01), 27-34. https://doi.org/10.53863/mor.v1i01.131

Ulfian, R. (2019). Pembinaan Olahraga Bulutangkis Di Klub PB Starta Kerinci Provinsi Jambi. Jurnal Pendidikan Dan Olahraga, 2(8), 53-58.

Widiyono, I. P., \& Mudiono. (2021). Keterampilan Dasar Futsal Peserta Ektrakurikuler di SMK Ma'arif 1 Kebumen Tahun Ajaran 2019/2020. JUMORA: Jurnal Moderasi Olahraga, 
1(01), 10-17. https://doi.org/10.53863/mor.v1i01.129

Widodo, P., \& Najibuzzamzam, A. (2021). Perbandingan Model Pembelajaran Daring Dan

Tatap Muka Penjaskes Mts Darussa'adah Pada Masa Pandemi Tahun Ajaran 2019/2020. JUMORA: Jurnal Moderasi Olahraga, 1(01), 1-9. https://doi.org/10.53863/mor.v1i01.128 